\title{
Lise Öğrencilerinin Spora Yönelik Farkındalık Düzeylerine Etki Eden Faktörlerin İncelenmesi: Tenis Branşı Örneği
}

\section{The Analysis of the Factors Influencing Sport Awareness Level of Secondary Education Students: Case of Tennis}

\author{
Araştırma Makalesi
}

Mehmet Ali ERGÜL', Cem TINAZ ${ }^{2}$, Mefharet ERTAÇ ${ }^{3}$

1 Şişli Mesleki ve Teknik Anadolu Lisesi, İstanbul

2 İstanbul Bilgi Üniversitesi, Spor Bilimleri ve Teknolojisi Yüksekokulu, Spor Yöneticiliği Bölümü, İstanbul

3 Serbest İstatistikçi, Münih, Almanya

\section{öz}

u araştırmanın amacı, lise öğrencilerinin tenis sporuna yönelik genel farkındalık düzeylerini cinsiyet, okul türü, sınıf düzeyi, ailenin eğitim durumu, mesleki durumu, sosyo-ekonomik durumu ve spora olan ilgi değişkenlerine ve bilişsel, duyuşsal ve psikomotor boyutlara göre analiz etmek, buna ilaveten özel okulda ve devlet okulunda okuyan öğrencilerin benzerliklerini ve farklııklarını incelemektir. Araştırmanın evrenini; İstanbul ili, Şişli ilçesinde okuyan öğrenciler, örneklemini ise Şişli Mesleki ve Teknik Anadolu Lisesi ve Notre Dame De Sion Fransız Lisesi'nde okuyan öğrenciler oluşturmaktadır. Bu araştırmanın örneklemini, İstanbul'da öğrenim gören lise öğrencileri içerisinden, araştırmanın amaçları doğrultusunda özel okul öğrencileriyle devlet okulu öğrencileri arasındaki benzerlik ve farklılıkları ortaya koyması beklenen, amaçlı örnekleme yöntemiyle seçilmiş 179'u kız ve 265 'i erkek olmak üzere toplam 444 katılımcı

\section{A B S T R A C T}

The purpose of this study is to investigate the general awareness level of the secondary education students in regards to tennis sport considering the variables based on their genders, school types, classroom levels, families educational status and their sport attention according to cognitive, affective, kinetic domains. The questionnaire was conducted on the students attending Sisli Vocational High School and French Notre Dame de Sion High School in Istanbul. 179 females, 265 males totally 444 students selected randomly participated in the study. In this study, quantitative and qualitative data were analyzed. Winter sport awareness questionnaire reformed by Eski (2010) and Personal Information Form created by the researcher exploited in collecting data. The findings of quantitative and qualitative data analysis conducted on research group were examined through SPSS 20.0 programme. $Z$ test was used for pairwise com- 
teşkil etmektedir. Araştırmada, ilişkisel tarama modeli kullanılmıştır. Verilerin toplanmasında Eski (2010) tarafından oluşturulmuş olan "Kış Sporları Farkındalık Ölçeği" esas alınarak geliştirilen "Tenis Sporu Farkındalık Düzeyi Ölçeği", kişisel verilerin toplanmasında yine Eski tarafından geliştirilen "Kişisel Bilgi Formu" kullanılmıştır. Elde edilen veriler SPSS 20.0 programında çözümlenmiştir. Karşılaştırmalar için İki Örnek z-Testi kullanılmıştır. Ayrıca bağımsız değişkenler için tanımlayıcı istatistikler (frekans ve yüzde) ve Spearman korelasyon katsayıları elde edilmiştir. Bu çalışmada hipotez testleri için anlamlılık düzeyi $(\alpha) 0.05$ olarak belirlenmiştir.

$\mathrm{Bu}$ araştırmanın sonuçlarına göre, öğrencilerin tenis sporuyla ilgili farkındalık düzeyine etki eden faktörlerin anlamlı farklılıklar gösterdiği belirlenmiştir. Sınıf düzeyi, anne-baba eğitim durumu, gelir durumu arttıkça farkındalık düzeyinin de arttığı tespit edilmiş tir. Ailesinde spor yapan ve yakın çevresinde tenis oynayanların olduğu öğrencilerde farkındalık düzeyinin daha yüksek olduğu tespit edilmiştir. Öğrencilerin genel farkındalık düzeyi "orta düzeyde farkında" olarak bulunmuştur. Alt boyutlara göre öğrencilerin duyuşsal farkındalıkları "oldukça farkında" olarak bulunmuştur.

\section{Anahtar Kelimeler}

Farkındalık, Tenis, Lise.

\section{GiRiş}

Yüksek yaşam standartlarını yakalamış olan ülkelerde beden eğitimi ve spor faaliyetlerinin, insanların yaşamla kurdukları bağın en önemli parçalarından biri olduğu gözlemlenebilir. Bu noktada amaçları ve hedefleri belirlenmiş beden eğitimi ve spor faaliyetleri ile ilgili bilgi, duygu ve hareket düzeyinde bir farkındalık oluşturulması gerekmektedir. Bu farkındalığın oluşturulması toplumun geleceğinin sağlıklı temeller üzerine oturtulması açısından da son derece önemlidir.

Spor, insanların yalnızca fiziksel gelişimini sağlamak amacında değildir. Aynı zamanda insanların hayatları boyunca öğrenmelerine ve katılımcı olmaya dair çeşitli bilgiler edinmelerine katkıda bulunur. Bu bağlamda spor, yalnızca sağlıklı ve mutlu olmanın, doyuma ulaşmanın bir yolu değil, aynı zamanda da bir eğitim aracıdır. Eğitimin insanların hayatları boyunca devam eden bir süreç olduğu göz önüne alındığında, spor herkes için olmalıdır ve insanlar bu konuyla ilgili bilinçlendirilmeli, toplumda farkındalık parisons. Frequency and \% (percentage) evaluating and analysis of Pearson correlation had been also used for independent variances. In this study, significance level for hypothesis tests had been decided as $(\alpha) 0.05$. Based on the findings of the research, the factors having an impact on students' awareness level had been analysed and meaningful differences had been determined. Furthermore; it had been determined that the more class level, parents' education statue, income status increase, the more students' awareness level increase. It was also revealed that the awareness level of the students who have parents doing sports and the students who have someone in their close environment playing tennis is much higher. The general awareness level of the students was determined as 'awareness in medium-level'. According to the subordinate groups the students' affective awareness had been obtained as 'notably aware'.

\section{Key Words}

Awareness, Tennis, High school

oluşturulmalıdır. Sporun sahip olduğu bu özelliklerden ötürü insanlara, bütün hayatları süresince kullanacakları bu güçlü eğitim aracından yararlanma alışkanlığı kazandırılmalıdır (Mirzeoğlu, 2011).

Günümüzde tenis sporu, dünyada ilgiyle takip edilen, rekreatif ve performans düzeylerinde yapılan, her yaştan her kişiye hitap eden popüler bir spor branşıdır. Öte yandan tenis, her boyutuyla yatırım gerektiren ve kısmen pahalı bir branştır. Eskiden yalnızca seçkinlerin oynadığı bir spor olan tenis, günümüzde kitle iletişim araçlarında elde ettiği görünürlük (televizyon, internet, gazete vb.), elit sporcuların popülaritesi, tenis etkinliklerinin bir iletişim mecrası olarak kullanılması sonucunda elde edilen ticari geri dönüşten ötürü artan sponsorluk ilgisi sayesinde her geçen gün gerek katılımcl, gerekse izleyici olarak daha fazla insanın ilgisini çekmektedir. Türkiye'de son dönemde düzenlenen uluslararası turnuvalar, profesyonel sporcularımızın 
dünya çapında elde ettiği başarılar, halk nezdinde, tenis sporu ile ilgili farkındalık oluşmasında etkili olan etkenlerden bazılarıdır.

Yapılan araştırmalardan elde edilen verilere göre üst düzey sporcuları vasat sporculardan ayıran en belirgin unsur farkındalık düzeylerinin yüksek bir noktada olmasıdır. Öte yandan psikolojik destek çalışmalarının ulaşmaya çalıştığı en üst yetkinlik, sporcuya kendisi hakkında farkında olma becerisini kazandırmaktır. Bu becerinin kazanılması ile sporcunun farkında olma düzeyi yükselir ve sporcu bu sayede beceriyle ilgili problemleri ve çözüm yollarını kolaylıkla keşfeder (Karagözoğlu, 2005).

Ülkemizdeki spor modeli, öğrencilerin spor hayatlarını kulüpler aracılığıyla sürdürdüğü bir modeldir. Ülkemizde spora katılımın sağladığı fiziksel, zihinsel ve ruhsal faydaların, gelecek ile ilgili endişelerin gölgesinde kaldığı bir anlayışın olduğunu söyleyebiliriz. Böyle bir anlayış, spor farkındalığının yeterli düzeyde olmadığı sonucunu doğurabilir.

Bu çalışmada özel okulda ve devlet okulunda okuyan lise öğrencilerinin tenis sporuna yönelik genel farkındalık düzeyleri cinsiyet, okul türü, sınıf düzeyi, ailenin eğitim durumu, mesleki durumları, sosyo-ekonomik durumları ve spora olan ilgi değişkenlerine göre bilişsel, duyuşsal ve psikomotor alt boyutlarıyla incelenmiştir.

Yapılan incelemede beden eğitimi ve spor alanında farkındalık ile ilgili yapılan çalışmalarda, lise öğrencilerinin tenis sporuyla ilgili farkındalık düzeylerini ele alan bir araştırmaya rastlanmamıştır. Ancak özellikle Eski (2010) tarafından yapılımıs olan doktora çalışması, spor ve farkındalık kavramlarını birlikte ele alması açısından önemli bir kaynak teşkil etmektedir. Yurt içinde yapılan çalışmalar incelendiğinde ise üniversite öğrencilerinin ve beden eğitimi öğretmenlerinin olimpiyatlarla ilgili farkındalıklarının araştırıldığı çalışmalar görülmüştür.

Eski (2010), “Lise Öğrencilerinin Kış Sporlarına Yönelik Farkındalık Düzeylerinin Değerlendirilmesi (Kastamonu İli Örneği)" konulu doktora tezinde, lisede okuyan öğrencilerin kış sporIarına yönelik farkındalık düzeylerini, bilişsel, duyuşsal ve psikomotor farkındalık alt boyutları ile değerlendirmiştir. Araştırma sonucuna göre lise öğrencilerinde kış sporlarına yönelik olarak genel bilişsel ve psikomotor farkındalığın, duyuşsal farkındalık alt boyutuna göre daha düşük olduğu tespit edilmiş, genel farkındalıkla bilişsel, duyuşsal ve psikomotor farkındalık boyutları, demografik değişkenlere göre anlamlı farklılıklar göstermiştir.

Kiremitçi (2012), “Problem Çözme Yöntemiyle Düzenlenmiş Beden Eğitimi Derslerinin, Problem Çözme Becerilerine Etkisi ve Üstbilişsel Farkındalık Düzeyleriyle İlişkisi" isimli araştırmasında; öğrencinin merkeze çekildiği problem çözme yöntemiyle uygulanan beden eğitimi derslerinin, klasik yöntemle yürütülen derslere oranla, öğrencilerin problem çözme becerilerinin gelişiminde anlamlı oranda etkili olduğu ve beden eğitimi derslerinde problem çözme yönteminin kullanılmasının, öğrencilerin üstbilişsel farkındalık düzeylerinin gelişimine katkıda bulunacağı sonucuna ulaşmıştır.

Gülşen (2012), TFF'nin 2011 yılında uyguladığı Futbol Köyü Projesi'ne katılan ilköğretim 12\$13 yaş kız ve erkek öğrencilerinin futbol branşına yönelik genel, bilişsel, duyuşsal ve psikomotor farkındalık düzeylerini cinsiyet değişkenine göre incelemiş̧tir. Araştırma sonucunda, araştırmaya katılan ilköğretim öğrencilerinin futbol branşına yönelik farkındalıklarının, erkek öğrencilerin genel, bilişsel ve psikomotor farkındalık türlerinde, kız öğrencilere göre yüksek olduğu görülürken, kız öğrencilerin ise duyuşsal farkındalıklarının erkek öğrencilere göre daha yüksek olduğu tespit edilmiştir.

Tenis sporuna dair yapılan araştırmalar incelendiğinde, İmamoğlu'nun (2009) Samsun ilinde 2008-2009 yıllarında "Samsun ilinde tenis sporu ile uğraşanların bu sporu seçme sebeplerinin araştırılması" isimli çalışmasında, araştırmaya katılanların tenis sporuna yönelmelerinin en önemli nedenleri arasında; ailenin öğrencileri teşvik etmesi, kitle iletişim araçlarının etkisi, arkadaş grubunun etkisi, yaşanılan çevredeki sportif etkinlikler ve yaşanılan çevrede tenis sporuna olan ilgi, hareket etme intiyacı gibi ne- 
denler olduğu görülmektedir. Ayrıca tenis sporu ile uğraşanların gelir düzeyinin orta ve üst gelir grubu olduğu, tenis sporundan beklentilerin ise; iyi bir fiziki görünüme sahip olmak, stres atmak, rahatlamak, serbest zaman aktivitesi yapmak, oyun oynamak, eğlenmek, performansı arttırmak, yeni bir çevre edinmek ve statü kazanmak olduğu sonucuna ulaşmıştır.

Şahin (2004) "Tenis, Kadın ve Sağlık" konulu araştırmasında; tenis sporunda beden, sosyoekonomik durum ve sağlık kavramları çerçevesinde sosyolojik bir analiz yapmıştır. Araştırma sonucuna göre tenisi, kentlileşmiş kadınların bir statü göstergesi olarak oynadıkları, böylece fiziksel sağlıklarını ve estetik güzelliklerini koruduklarını düşündükleri ortaya çıkmıştır.

Yabancı çalışmaların ise fiziksel aktivite esasları ve politikalarına ilişkin farkındalık, antidoping farkındalığı, beden eğitimi öğretmenlerinin öğrencilerindeki astım ile ilgili farkındalıkları, oyun derslerindeki taktiksel farkındalık gibi çeşitli konularda yapıldığı görülmektedir (Eski, 2010).

Lise öğrencilerinin beden eğitimi ve spor alanında gelecek hedeflerinin gerçekleştirilmesinde ilk olarak farkındalık düzeylerinin ve bu duruma etki eden faktörlerin bilimsel çalışmalardan elde edilen verilerle tespit edilmesi gelecekle ilgi kararların alınabilmesi açısından son derece önem taşımaktadır (Eski, 2010). Bu araştırmanın amacı, lise öğrencilerinin tenis sporuna yönelik genel farkındalık düzeylerini cinsiyet, okul türü, sınıf düzeyi, ailenin eğitim durumu, mesleki durumu, sosyo-ekonomik durumu ve spora olan ilgi değişkenlerine ve bilişsel, duyuşsal ve psikomotor alt boyutlarına göre analiz etmek, buna ilaveten özel okulda ve devlet okulunda okuyan öğrencilerin benzerliklerini ve farklılıklarını incelemektir.

Bu çalışma lise öğrencilerinin tenis sporuna yönelik farkındalık düzeylerinin çeşitli değişkenlere göre düşük ise bunun sebeplerinin belirlenmesi, belirlenen bu sebeplere göre çeşitli öneriler sunulması, öğrencilerin tenis sporuna katılımını engelleyen sebeplerin belirlenmesi ve değerlendirilerek çözüm yolları sunulması açısından önemlidir. Bu araştırma ülkemizde tenis sporuna yönelik ortaokul öğrencileri nezdinde farkındalık düzeyini ölçen ilk araştırma olduğundan önem arz etmektedir. Ülkemizde tenis sporunu yöneten idarecilerin araştırmadan elde edilen bulguları göz önünde bulundurarak, stratejilerini belirlemeleri hedeflerine daha kolay ulaşmalarını mümkün kılacağı umulmaktadır. Bu bağlamda yorum yapılabilmesi ve hedeflenen sonuçlara ulaşılması için bazı temel kavramlara açıklık getirilmelidir.

\section{Farkındalık}

Sporda farkındalık ve farkındalığı etkileyen faktörler üzerine uluslararası literatürde fazlasıyla çalışma yapılmıştır (Cialdini ve diğ., 1976; Funk ve diğ., 2000; Hill ve Green, 2000; Kolbe ve James, 2000; Milne ve McDonald, 1999; Sloan, 1989; Wann, 1995). Ancak bu çalışmaların birçoğu taraftar farkındalığı, marka farkındalığı, sponsorluk farkındalığı gibi farklı konulardaki farkındalık düzeylerini ve farkındalığı etkileyen faktörleri incelemişlerdir.

"Farkındalık var olan ana odaklanmak ve anlık yaşantılara yönelmekle ilgilidir. Basit gibi görünen bu açıklamaya karşın, farkındalık çok yönlü bir kavramdır. Bu sebeple literatürde farkındalığı farklı yönleriyle ele alan tanımlar bulunduğu görülmektedir" (Çatak ve Ögel, 2010). Kabat-Zinn (2003), farkındalığı, dikkatin istemli bir şekilde ve yargısızca anlık yaşantıların akışına yöneltilmesi olarak ifade etmiştir. Farkında olma, bilişsel ve duyuşsal bir faaliyettir. Farkında olma işlemi tamamlandığında, birtakım yeni zihinsel şemalar ve imgeler oluşturmuş oluruz. Yeni şema oluşturmak, bilinç alanının gelişmesi ve genişlemesi anlamına gelir. Farkına varma yoluyla, kendimize, çevremize ve evrene ilişkin bilinç düzeyimizde artma olur; bilinç alanımız genişler (Dökmen, 2002). "Farkındalıkla ilgili tanımlamaların bir bölümü, kavramı temel bilişsel süreçler açısından ele almaktadır. Farkındalık, uyarıcıların değerlendirilmediği, sınıflandırılmadığı ve analiz edilmediği, kendine özgü açık ve alıcı bir bilinç formu olarak tanımlanmaktadır" (Çatak ve Ögel, 2010). Yaşantı döngüsünün veya 
birey-çevre temasının gerçekleşebilmesi için temel unsur, farkındalığın olmasıdır.

Farkındalık için yapılan diğer bir tanımda ise farkındalık niyet, dikkat ve tutum bileşenlerinden oluşan üç parçalı bir modelde açıklanmıştır. Tanımda yer alan niyet bileşeni, şimdi ve buradaki anlık yaşantıya odaklanma istemini, dikkat bileşeni, dikkatin devamlı bir şekilde anlık deneyimleri gözlemlemek üzere düzenlenmesini, tutum bileşeni ise anlık yaşantılara yaklaşımın açıklık, kabullenme, yansızlık gibi özelliklerini ifade etmektedir. Farkındalığı açıklayan bu modele göre, farkındalık, "yeniden algılama" olarak adlandırılan bir meta-mekanizma aracılığı ile, benlik regülasyonu, değerlerin netleşmesi, bilişsel ve davranışsal esneklik ve maruz kalma gibi bir takım değişikliklere neden olmaktadır (Shapiro ve diğ., 2006). Özetle farkındalık kavramı bireyin, tüm duyularıyla, başka bir birey veya çevresiyle temasa geçerken, neyi, nasıl yaşadığının bilincinde olmasıdır (Acar, 2009).

Spor farkındalığını ölçümlemek üzere uluslararası literatürde kabul görmüş bazı modeller bulunmaktadır. Sporun psiko-sosyal alanlarında çalışmalar yapan, dünyanın önce gelen akademisyenlerinden Funk ve James (2001) geliştirdikleri Psikolojik Süreç Modeli (PCM) ile taraftar olgusunun ortaya çıkmasını tetikleyen süreçleri nitelemişlerdir. Bu süreçlerin ilki farkındalık olarak tanımlanmıştır. Alıcının başka bir deyişle bu çalışmanın odağında yer alan lise öğrencilerinin, maruz kaldıkları bir mesaja verecekleri tepki karmaşıktır ve bundan ötürü bu tepkinin önceden kestirilmesi zordur. Kişinin mesaja vereceği tepkide rol oynayan faktörlere örnek olarak, mesajın ana öğesinin özellikleri, kişinin içinde bulunduğu durum, sosyal, psikolojik, çevresel ve kültürel faktörler sayılabilir. Literatürde Maslow'un "Etkiler Hiyerarşisi" teorisini (Maslow, 1970) esas alan birçok teori bulunmaktadır. AIDA (Attention-Interest-Desire-Action) modeli (Barry, 1990), Lavidge ve Steiner Modeli (Lavidge ve Steiner, 1961), Colley'in geliştirmiş olduğu DAGMAR modeli (Dutka, 1995) gibi modeller kısmen geçerliliklerini yitirmiş olsalar da, halen farkındalık düzeyi çalışmalarına temel teşkil etmektedirler.

\section{Beden eğitimi ve spor alanında farkındalık}

"Bireyin yaşamı boyunca gelişiminin ve dönüşümünün başlangıç noktası; farkına varmaktır" (Karakuş, 2008, s. 74). Erdemli (1996) beden eğitimi kavramının ön koşulu olan hareket eğitimi ile ilgili olarak, insanın en belirgin özelliklerinin başında onun bir eylem varlığı olması geldiğini ifade etmiştir. Bu yüzden insanın varlığını gerçekleştirmesi de varlığını devam ettirmesi de, kendi eylemine bağlıdır. Hareket eğitimi insanın bedenine ve onun dili olan harekete yeni anlam vermektedir. Hareket, insan varlığının temel koşuludur. Insan çevresini hareketle algılar, dış dünyasını hareketle keşfeder. Hareket toplumun bir iletişim aracıdır. Beden eğitiminin, sporun, oyunların ve yaşamın merkezinde hareket vardır (Mirzeoğlu, 2011). Farkına varma, fark etme, farkında olma, kendinden haberdar olma gibi kavramlar insanın bilişsel yeterlikleri, duyuşsal özellikleri, psikomotor becerileri ile ilgili durumIarını belirtir. İnsan bütün duyu organlarını kullanarak kendisi ve çevresi ile temasa geçerken neleri bildiğini, neyi düşündüğünü, nasıl hissettiğini birbirinden ayırt edebilir ve bunları istekleri ve intiyaçları doğrultusunda yaşantısının herhangi bir anında uygulayabilir. Beden eğitimi ve spor alanındaki farkındalık, bilişsel, duyuşsal ve psikomotor alanları içinde barındıran geçmişten geleceğe doğru uzanan ancak bireyin yaşantısının yaşadığı andaki seçiciliğinin gerçekleştiği zamandır (Eski, 2010). Öğrenciler fiziksel etkinlikler aracııı̆ıyla, sağlığın, güzel vücut hareketlerinin ve alıştırma ilkelerinin yaşamlarındaki yerini öğrenerek bunun önemini kavrarlar. Sağlıklı olmanın ve fiziksel uygunluğun değerini ve bunların nasıl geliştirilerek korunduğunu öğrenirler. Öğrencilerin deneyimleyebildikleri başka bir nokta da, beden eğitimi yoluyla kendilerinin zayıf ve güçlü yönlerini test etme olanağı bulmaları olacaktır (Tamer ve Pulur, 2001). Böylece sınırlarının bilincinde olarak yapabilecekleri ve yapamayacakları fiziksel etkinliklerin farkına varmış olacaklardır. Bütün beden eğitimi faaliyetleri toplumsal bir deniyimdir ve çoğu zaman duyguları içinde barındırırlar. Bu tür faaliyetlere 
katılan insanlar, hareketler aracılığı ile duygularını ifade etme fırsatı bulurlar. Insanlar spor aracılığıyla saldırganlık, öfke, utangaçlık, kıskançlık vb. duygularında boşalım sağlarlar, bu duygularını kontrol etmesini öğrenirler (Aracı, 1999, s.31). Öğretmenler beden eğitimi derslerinde öğrencilerin duyuşsal alanda da gelişmelerini desteklemeyi amaçlayarak, bütün bir yıl boyunca öğretecekleri etkinliklerde öğrencilerin beraber çalışmaları için olanaklar yaratmalı, böylece onların sosyalleşmelerine ve işbirlikçi öğrenmelerine fırsat vermelidirler. Bu tür etkinlikler aynı zamanda öğrencilerin olumlu benlik geliştirmelerine de yardımcı olur. Beden eğitiminin temel bakış açısını psikomotor alandaki farkındalık oluşturur. Beden eğitimi dersleriyle diğer alanlarda (bilişsel, duyuşsal) da farkındalık hedeflense de, bir beden eğitimi öğretmeninin temel görevi öğrencilerinin psikomotor farkındalıklarına katkıda bulunacağı alanlar yaratmaktır. Psikomotor farkındalık, bilişsel ve duyuşsal farkındalığın bireyi daha somut davranışla, doğal ve sosyal çevrenin etkisi ile katılıma yöneltmesi, eyleme geçirmesidir (Eski, 2010).

\section{YÖNTEM}

Örneklem: Araştırmanın evrenini; İstanbul ili, Şişli ilçesindeki öğrenciler, örneklemini ise Şişli Mesleki ve Teknik Anadolu Lisesi ve Notre Dame De Sion Fransız Lisesindeki öğrenciler oluşturmaktadır. Bu araştırmanın örneklemini, İstanbul'da öğrenim gören lise öğrencileri içerisinden, araştırmanın amaçları doğrultusunda özel okul öğrencileriyle devlet okulu öğrencileri arasındaki benzerlik ve farklılıkları ortaya koyması beklenen, amaçlı örnekleme yöntemiyle seçilmiş 179'u kız ve 265 'i erkek olmak üzere toplam 444 katılımcı teşkil etmektedir. Bu örneklemenin temeli, araştırmanın amaçları doğrultusunda bir evrenin temsilci bir örneği yerine, amaçlı olarak bir ya da birkaç alt kesimini örnek olarak almaktır. Başka bir deyişle amaçlı örnekleme, evrenin soruna en uygun bir kesimini gözlem konusu yapmak demektir (Sencer, 1989; İslamoğlu, 2003).

Veri Toplama Araçları: Verilerin toplanmasında Eski (2010) tarafından oluşturulmuş olan
"Kış Sporları Farkındalık Öıçeği" esas alınarak geliştirilen "Tenis Sporu Farkındalık Düzeyi Ölçeği" kullanılmıştır. Ölçek geçerlilik testine uzman görüşü alınarak son şekli verilmiş, son şekli verilen anket geçerlik ve güvenirlik testi için 65 kişilik bir ön gruba uygulanmış Cronbach Alpha katsayısı $\alpha=0,85$ olarak bulunmuştur.

5'li Likert tipi olan bu ölçek, "Kişisel Bilgiler ve Farkındalık" düzeyini ölçen 2 bölümden oluşmaktadır. "Kişisel Bilgiler" bölümü 11 sorudan, “Tenis Sporu Farkındalık Düzeyi Ölçeği" 35 sorudan oluşmaktadır ve bilişsel, duyuşsal ve psikomotor olmak üzere 3 alt boyuta sahiptir.

Araştırma için geliştirilen ölçek formu, araştırmanın örneklem grubunu oluşturan öğrencilerin devlet okulunda öğrenim görenlerine dağıtılmış, öğrencilere dikkat edilmesi gereken bilimsel kurallar tek tek açıklanarak verilmiştir. Aynı ölçek formu araştırmanın diğer örneklem grubu olan özel okuldaki öğrencilerin öğretmenlerine bilimsel kurallar açıklanarak teslim edilmiştir. Bu bağlamda Şişli Teknik ve Anadolu Meslek Lisesi ile Notre Dame De Sion Fransız Lisesi'nde okuyan 220'si kız, 280'i erkek olmak üzere amaçlı örnekleme yöntemi ile seçilmiş 500 lise öğrencisine anket uygulanmıştır.

Kişisel bilgi formu: Birinci bölümde yer alan kişisel bilgiler; cinsiyet, okul türü, sınıf düzeyi, annenin öğrenim durumu, babanın öğrenim durumu, annenin iş durumu, babanın mesleği, ailenin ortalama aylık geliri, ailede spor yapanlar, ailede tenis sporu ile ilgilenenler gibi öğrencilerle ile ilgili bilgileri toplamak amacıyla araştırmacı tarafından hazırlanmıştır. Araştırmanın bağımsız değişkenleri, aynı zamanda "Kişisel Bilgi Formunda" yer alan değişkenlerden oluşmaktadır.

Tenis sporu farkındalık düzeyi ölçeği: Öğrencilerin kış sporlarına yönelik farkındalık düzeylerini ölçmeye yönelik hazırlanan ve Eski (2010) tarafından geliştirilen ölçme aracı, tenis sporuna yönelik olarak uyarlanmıştır. Ölçek, bilişsel, duyuşsal ve psikomotor olmak üzere 3 alt boyuttan oluşmaktadır. Ölçme aracında bilişsel farkındalık düzeyinde 13, duyuşsal farkındalık düzeyinde 13 ve psikomotor farkındalık düze- 
yinde 9 madde olmak üzere toplam 35 madde bulunmaktadır. Her bir maddenin değerlendirilmesinde beşli likert ölçeği kullanılmış ve boyutlardaki ifade sayıları farklı olduğu için boyut puanlarının oluşturulmasında boyutu oluşturan maddelerin ortalaması alınmıştır.

Verilerin Analizi: 500 lise öğrencisine uygulanan anketlerden yanlış ve eksik doldurulan anketler çıkarıldıktan sonra geçerli sayılan 444 anket değerlendirilmiştir. Toplam 35 maddeden oluşan ölçme aracı ile toplanan veriler bilgisayar ortamında SPSS 20.0 (Statistical Package For The Social Science For Windows) programı ile analiz edilmiştir. Analizlerde yer alan problem cümlelerini okul türü bazında karşılaştırabilmek amacıyla iki Örnek z-Testi kullanılmıştır. Ayrıca bağımsız değişkenler için tanımlayıc istatistikler (frekans ve yüzde) ve değişkenler arasındaki ilişki derecelerini ölçmek için Spearman korelasyon katsayıları elde edilmiştir. Bu çalışmada hipotez testleri için anlamlılık düzeyi $(\alpha) 0.05$ olarak belirlenmiştir.

Geliştirilen anket formu taslağında beşli likert tipi dereceleme ölçeği kullanılmıştır. Olumlu maddelere verilecek cevap kodları 1,00 ile 5,00 arasında; 1= Hiç Katılmıyorum, 2= Az Katılıyorum, 3= Orta Derecede Katılıyorum, 4= Oldukça Katılıyorum, 5= Tamamen Katılıyorum şeklinde değişmektedir. Olumsuz maddelere verilecek cevap kodları ise 5,00 ile 1,00 arasında değişmektedir. Ölçek maddelerinde yer alan aralıkların eşit olduğu $(N-1 / N=4 / 5=0,80)$ varsayımından hareketle seçeneklere ait sınırlar belirlenerek Tablo 1'de verilmiştir.

Tablo 1. Seçenek sınırları

\begin{tabular}{|c|c|c|}
\hline $\begin{array}{l}\text { Cevap } \\
\text { Kodları }\end{array}$ & Sınırlar & Seçenekler \\
\hline 1 & $1,00-1,80$ & Farkında değil \\
\hline 2 & $1,81-2,60$ & $\begin{array}{l}\text { Az düzeyde } \\
\text { farkında }\end{array}$ \\
\hline 3 & $2,61-3,40$ & $\begin{array}{l}\text { Orta düzeyde } \\
\text { farkında }\end{array}$ \\
\hline 4 & $3,41-4,20$ & Oldukça farkında \\
\hline 5 & $4,21-5,00$ & $\begin{array}{l}\text { Tamamen } \\
\text { farkında }\end{array}$ \\
\hline
\end{tabular}

\section{BULGULAR}

Şişli Teknik ve Anadolu Meslek Lisesi ile Notre Dame De Sion Fransız Lisesi öğrencilerinin tenis farkındalığına etki eden faktörleri, çeşitli demografik değişkenlere göre karşılaştırarak inceleme-

Tablo 2. Demografik değişkenlere ilişkin frekans ve yüzde dağılımları

\begin{tabular}{|c|c|c|c|}
\hline Değişkenler & $\begin{array}{c}\text { Alt } \\
\text { kategoriler }\end{array}$ & $\begin{array}{c}\text { Frekans } \\
\text { (n) }\end{array}$ & $\begin{array}{c}\text { Yüzde } \\
(\%)\end{array}$ \\
\hline \multirow{2}{*}{ Cinsiyet } & KıZ & 179 & 40,3 \\
\hline & Erkek & 265 & 59,7 \\
\hline \multirow[b]{2}{*}{ Okul Türü } & $\begin{array}{l}\text { Şişli End. } \\
\text { Mes.Lis. }\end{array}$ & 282 & 63,5 \\
\hline & $\begin{array}{c}\text { Notre } \\
\text { Dame De } \\
\text { Sion }\end{array}$ & 162 & 36,5 \\
\hline \multirow{4}{*}{ Sinıf } & 9. sinıf & 142 & 32 \\
\hline & 10. sınıf & 132 & 29,7 \\
\hline & 11. sınıf & 116 & 26,1 \\
\hline & 12. sınıf & 54 & 12,2 \\
\hline \multirow{6}{*}{$\begin{array}{l}\text { Anne } \\
\text { Öğrenim } \\
\text { Durumu }\end{array}$} & $\begin{array}{c}\text { Okur-yazar } \\
\text { değil }\end{array}$ & 25 & 5,6 \\
\hline & İlköğretim & 207 & 46,6 \\
\hline & Lise & 84 & 18,9 \\
\hline & Yüksekokul & 82 & 18,5 \\
\hline & $\begin{array}{l}\text { Lisans ve } \\
\text { üstü }\end{array}$ & 46 & 10,4 \\
\hline & $\begin{array}{c}\text { Okur-yazar } \\
\text { değil }\end{array}$ & 7 & 1,6 \\
\hline \multirow{4}{*}{$\begin{array}{l}\text { Baba } \\
\text { Öğrenim } \\
\text { Durumu }\end{array}$} & İlköğretim & 174 & 39,2 \\
\hline & Lise & 98 & 22,1 \\
\hline & Yüksekokul & 95 & 21,4 \\
\hline & $\begin{array}{l}\text { Lisans ve } \\
\text { üstü }\end{array}$ & 70 & 15,8 \\
\hline \multirow{6}{*}{$\begin{array}{l}\text { Annenizin } \\
\text { Mesleği }\end{array}$} & Ev hanımı & 266 & 59,9 \\
\hline & $\begin{array}{l}\text { Serbest } \\
\text { meslek }\end{array}$ & 44 & 9,9 \\
\hline & İşçi & 52 & 11,7 \\
\hline & Memur & 31 & 7 \\
\hline & Emekli & 16 & 3,6 \\
\hline & $\begin{array}{l}\text { İş yeri } \\
\text { sahibi }\end{array}$ & 35 & 7,9 \\
\hline
\end{tabular}




\begin{tabular}{|c|c|c|c|}
\hline Değişkenler & $\begin{array}{c}\text { Alt } \\
\text { kategoriler }\end{array}$ & $\begin{array}{l}\text { Frekans } \\
\text { (n) }\end{array}$ & $\begin{array}{c}\text { Yüzde } \\
\text { (\%) }\end{array}$ \\
\hline \multirow{6}{*}{$\begin{array}{l}\text { Babanızın } \\
\text { Mesleği }\end{array}$} & İşsiz & 13 & 2,9 \\
\hline & $\begin{array}{l}\text { Serbest } \\
\text { meslek }\end{array}$ & 114 & 25,7 \\
\hline & İşçi & 120 & 27 \\
\hline & Memur & 38 & 8,6 \\
\hline & Emekli & 42 & 9,5 \\
\hline & $\begin{array}{l}\text { İş yeri } \\
\text { sahibi }\end{array}$ & 117 & 26,4 \\
\hline \multirow{5}{*}{$\begin{array}{l}\text { Ailenizin } \\
\text { ortalama } \\
\text { aylık geliri }\end{array}$} & 800 ve altı & 18 & 4,1 \\
\hline & $801-1200$ & 81 & 18,2 \\
\hline & $1201-2500$ & 126 & 28,4 \\
\hline & $\begin{array}{l}2501- \\
4000\end{array}$ & 61 & 13,7 \\
\hline & $\begin{array}{c}4001 \text { ve } \\
\text { üzeri }\end{array}$ & 158 & 35,6 \\
\hline \multirow{2}{*}{$\begin{array}{l}\text { Ailenizde } \\
\text { spor yapan } \\
\text { var mı? }\end{array}$} & Evet & 217 & 48,9 \\
\hline & Hayır & 227 & 51,1 \\
\hline \multirow{2}{*}{$\begin{array}{l}\text { Aileniz ya } \\
\text { da yakın } \\
\text { çevrenizde } \\
\text { tenis ile } \\
\text { ilgilenen var } \\
\text { mı? }\end{array}$} & Evet & 108 & 24,3 \\
\hline & Hayır & 336 & 75,7 \\
\hline \multirow{5}{*}{$\begin{array}{l}\text { Bildiğiniz üç } \\
\text { tane tenis } \\
\text { sporcusunu } \\
\text { yazınız }\end{array}$} & Hiç Yok & 113 & 25,5 \\
\hline & 1 & 5 & 13,1 \\
\hline & 2 & 54 & 12,2 \\
\hline & 3 & 129 & 49,3 \\
\hline & Toplam & 444 & 100 \\
\hline
\end{tabular}

ye yönelik olarak yapılan bu araştırma, amaçlı örnekleme yöntemiyle seçilmiş 179'u kız, 265'i erkek toplam 444 lise öğrencisinin gönüllü katılımı ile gerçekleştirilmiştir. Demografik bulgulara ait veriler tablo halinde aşağıda verilmiştir.

Araştırmaya katılan öğrencilerin tenis sporuna dair farkındalık düzeyleri toplam 35 ifade aracılığıyla bilişsel, duyuşsal ve psikomotor alt boyutlarına indirgenerek ölçümlenmiştir. Öğrencilerin farkındalık düzeylerine ilişkin bulgular şu şekildedir.

Tablo 3 incelendiğinde araştırmaya katılan öğrencilerin tenis sporuna dair bilişsel farkındalık düzeyleri "orta düzeyde farkında" olarak tespit edilmiştir. Bilişsel farkındalık alt boyutuyla ilgili, "Tenis sporunda kullanılan ekipmanlar hakkında bilgi sahibiyim (raket, top, file ve direkler)" ile "Tenis sporunda kullanılan giyim malzemeleri (forma, şort, çorap, ayakkabı) hakkında bilgim vardır" gibi ifadelere katılım düzeyine göre öğrencilerin "oldukça farkında" oldukları tespit edilmiştir.

Duyuşsal farkındalık düzeyine ilişkin bulgular incelendiğinde, öğrencilerin duyuşsal farkındalıklarının diğer alt boyutlara göre yüksek değerler alarak "oldukça farkında" olduğu görülmüştür. En düşük değeri “Düzenlenecek organizasyonlar insanların tenis hakkında bilgi seviyesini değiş̧tirmez" ifadesinin aldığı görülmektedir.

Psikomotor farkındalık boyutuyla ilgili sorular yönelik değerlendirildiğinde ise, öğrencilerin psikomotor boyutta "az düzeyde farkında" oldukları görülmektedir. Psikomotor boyutta en yüksek değeri alan ifade ise "Yerel yönetimlerin tenisin gelişimine önem vermesi gerektiğini düşünüyorum" olmuştur.

Elde edilen bulgular incelendiğinde öğrencilerin duyuşsal farkındalıklarının, bilişsel ve psikomotor farkındalıklarına oranla belirgin bir şekilde yüksek çıktığı görülmektedir. Öğrencilerin bilişsel farkındalık düzeylerinin ise, psikomotor farkındalık düzeyine göre daha fazla olduğu görülmektedir. Elde edilen bulgulara göre duyuşsal farkındalık düzeyi "oldukça farkında", bilişsel farkındalık düzeyi "orta düzeyde farkında", ve psikomotor farkındalık düzeyi "az düzeyde farkında" olarak tespit edilmiştir.

Bu araştırmada i̇stanbul'da devlet okullarıyla özel okullarda öğrenim gören lise öğrencilerinin, tenis sporuna yönelik farkındalığını etkileyen faktörler çeşitli demografik değişkenler dikkate alınarak incelenmiştir. Bulgular değerlendirilirken özellikle üzerinde durulacak değişkenlerden biri okul türüdür. Okul türüne bağlı olarak öğrencilerin tenis sporuna dair farkındalık düzeylerinde belirgin farklılıklar olduğu öngörülmektedir. Aşağıdaki tabloda okul türü değişkeni ile farkındalık ölçeğinde yer alan ifadeler arasında anlamlı farklılıklar olanlara yer verilmiştir.

Bu tablolardaki $p$ değerleri $\alpha / 2$ değerleri ile karşılaştırılmıştır. "Ailem bana tenis sporu ile ilgili 
Tablo 3. Bilişsel farkındalık düzeyi bulguları

\begin{tabular}{|c|c|c|c|c|c|}
\hline & & & $\mathbf{n}$ & Ortalama & $\begin{array}{l}\text { Standart } \\
\text { Sapma }\end{array}$ \\
\hline \multirow{13}{*}{ 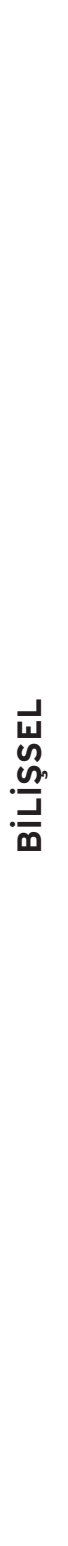 } & 1 & $\begin{array}{c}\text { Ailem bana tenis sporu ile ilgili bilgi } \\
\text { vermektedir }\end{array}$ & 444 & 2,32 & 1,461 \\
\hline & 2 & Tenis sporunun kurallarını biliyorum & 444 & 2,84 & 1,405 \\
\hline & 3 & $\begin{array}{l}\text { Tenis sporu ile ilgili düzenlenen } \\
\text { turnuvalar hakkında bilgim vardır }\end{array}$ & 444 & 2,52 & 1,353 \\
\hline & 4 & $\begin{array}{l}\text { Çevremizde bulunan tenis kortları } \\
\text { hakkında bilgi sahibiyim }\end{array}$ & 444 & 2,54 & 1,377 \\
\hline & 5 & $\begin{array}{c}\text { Türkiye'deki tenis kulüpleri hakkında bilgi } \\
\text { sahibiyim }\end{array}$ & 444 & 2,37 & 1,298 \\
\hline & 6 & $\begin{array}{c}\text { Türkiye'de yapılan tenis sporu hakkında } \\
\text { bilgi sahibiyim }\end{array}$ & 444 & 2,47 & 1,3 \\
\hline & 7 & $\begin{array}{l}\text { Türkiye'de tenis sporunun yaygın } \\
\text { olduğunu düşünüyorum }\end{array}$ & 444 & 2,61 & 1,266 \\
\hline & 8 & $\begin{array}{c}\text { Tenis sporunda kullanılan ekipmanlar } \\
\text { hakkında bilgi sahibiyim (raket, top, file } \\
\text { ve direkler) }\end{array}$ & 444 & 3,53 & 1,348 \\
\hline & 9 & $\begin{array}{l}\text { Tenis sporunda kullanılan giyim } \\
\text { malzemeleri (forma, şort, çorap, } \\
\text { ayakkabı) hakkında bilgim vardır }\end{array}$ & 444 & 3,33 & 1,374 \\
\hline & 10 & $\begin{array}{l}\text { Yaşadığım çevrenin tenis oynamak için } \\
\text { uygun olduğunu düşünüyorum }\end{array}$ & 444 & 2,72 & 1,478 \\
\hline & 11 & $\begin{array}{l}\text { Türkiye'de tenis merkezlerinin hangi il ve } \\
\text { bölgelerde bulunduğunu bilmiyorum }\end{array}$ & 444 & 2,74 & 1,385 \\
\hline & 12 & $\begin{array}{c}\text { Teniste başarılı olan sporcuların isimlerini } \\
\text { sayabilirim }\end{array}$ & 444 & 2,84 & 1,429 \\
\hline & 13 & $\begin{array}{c}\text { Çevremizde yapılan tenis turnuvaları } \\
\text { hakkında bilgim vardır }\end{array}$ & 444 & 2,39 & 1,292 \\
\hline
\end{tabular}

bilgi vermektedir" ifadesi ile "Okul Türü" değişkeni arasında $\mathrm{p}<.025$ olduğundan bu kriter için okul türleri arasında anlamlı bir farklılık elde edilmiştir. Buna göre Notre Dame De Sion öğrencilerinin aileleri Şişli End. Mes. Lisesi öğrencilerinin ailelerine kıyasla tenis sporu ile ilgili çocuklarını daha fazla bilgilendirdikleri söylenebilir. Benzer şekilde Notre Dame De Sion öğrencilerinin Şişli End. Mes. Lisesi öğrencilerine göre Türkiye'de yapılan tenis sporu hakkında ve tenis sporunda kullanılan ekipmanlar hakkında (raket, top, file ve direkler) daha fazla bilgiye sahip olduğu ve Notre Dame De Sion Lisesi öğrencileri Şişli End. Mes. Lisesi öğrencilerine kıyasla, bölgelerinde bulunan tenis kortlarına daha fazla gidebildikleri görülmektedir. "Ekonomik nedenlerden dolayı tenis kortlarına gidemiyorum" ifadesi ile "Okul Türü" değişkeni arasında $\alpha=0.05$ düzeyinde anlamlı bir farklılık bulunmuştur. Şişli End. Mes. Lisesi öğrencilerinin Notre Dame De Sion Lisesi öğrencilerine kıyasla, ekonomik nedenlerden dolayı tenis kortlarına gidemedikleri söylenebilir. 
Tablo 4. Duyuşsal farkındalık düzeyine ilişkin bulgular

\begin{tabular}{|c|c|c|c|c|c|}
\hline & & & $\mathbf{n}$ & Ortalama & $\begin{array}{l}\text { Standart } \\
\text { Sapma }\end{array}$ \\
\hline \multirow{13}{*}{$\begin{array}{l}\frac{1}{4} \\
\text { s } \\
\text { s. } \\
2 \\
2 \\
2\end{array}$} & 14 & $\begin{array}{c}\text { Tenis sporunun insan dayanıklılığını arttırdığını } \\
\text { düşünüyorum }\end{array}$ & 444 & 3,32 & 1,353 \\
\hline & 15 & $\begin{array}{c}\text { Düzenlenecek organizasyonlar tenise olan } \\
\text { ilgiyi arttırır }\end{array}$ & 444 & 3,45 & 1,32 \\
\hline & 16 & $\begin{array}{c}\text { Düzenlenecek organizasyonlar bölgemize } \\
\text { ekonomik katkı sağlar }\end{array}$ & 444 & 3,34 & 1,286 \\
\hline & 17 & $\begin{array}{c}\text { Düzenlenecek organizasyonlar bölgemizdeki } \\
\text { tesislerin gelişmesini sağlar }\end{array}$ & 444 & 3,45 & 1,313 \\
\hline & 18 & $\begin{array}{l}\text { Düzenlenecek organizasyonlar kültürümüzün } \\
\text { ve kentimizin tanıtımına, turizme katkı sağlar }\end{array}$ & 444 & 3,52 & 1,326 \\
\hline & 19 & $\begin{array}{c}\text { Düzenlenecek organizasyonlar bölgede yetişen } \\
\text { sporcu sayısının artmasını sağlar }\end{array}$ & 444 & 3,63 & 1,306 \\
\hline & 20 & $\begin{array}{c}\text { Düzenlenecek organizasyonlar tenisin tanıtımı } \\
\text { konusunda katkı sağlar }\end{array}$ & 444 & 3,45 & 1,417 \\
\hline & 21 & $\begin{array}{c}\text { Düzenlenecek organizasyonlar insanların tenis } \\
\text { hakkında bilgi seviyesini değiştirmez }\end{array}$ & 444 & 2,25 & 1,245 \\
\hline & 22 & $\begin{array}{l}\text { Tenis eğitiminin ilköğretim I. kademesinden } \\
\text { itibaren başlatılması gerektiğini düşünüyorum. }\end{array}$ & 444 & 3,26 & 1,314 \\
\hline & 23 & $\begin{array}{l}\text { Okulumuzda en az bir tenis kortunun olması } \\
\text { gerektiğini düşünüyorum }\end{array}$ & 444 & 3,5 & 1,356 \\
\hline & 24 & $\begin{array}{c}\text { Beden eğitimi derslerinde tenis sporunun } \\
\text { tanıtılmadığını düşünüyorum }\end{array}$ & 444 & 3,45 & 1,347 \\
\hline & 25 & $\begin{array}{l}\text { Yerel yönetimlerin tenisin gelişimine önem } \\
\text { vermesi gerektiğini düşünüyorum }\end{array}$ & 444 & 3,36 & 1,279 \\
\hline & 26 & $\begin{array}{l}\text { Tenis ile ilgili eğitim merkezlerinin açılması } \\
\text { gerektiğini düşünüyorum }\end{array}$ & 444 & 3,4 & 1,251 \\
\hline
\end{tabular}

Tablo 5. Psikomotor farkındalık düzeyine ilişkin bulgular

\begin{tabular}{|c|c|c|c|c|c|}
\hline & & & $\mathbf{n}$ & Ortalama & $\begin{array}{l}\text { Standart } \\
\text { Sapma }\end{array}$ \\
\hline \multirow{9}{*}{ 岕 } & 27 & $\begin{array}{l}\text { Okulumuzda tenis turnuvası } \\
\text { düzenlenirse katılırım }\end{array}$ & 444 & 2,94 & 1,362 \\
\hline & 28 & $\begin{array}{c}\text { Tenis sporunu kurallarına göre } \\
\text { yapıyorum }\end{array}$ & 444 & 2,58 & 1,357 \\
\hline & 29 & $\begin{array}{l}\text { Tenisi spor tesislerinde ya da uygun } \\
\text { alanlarda yapıyorum }\end{array}$ & 444 & 2,48 & 1,391 \\
\hline & 30 & $\begin{array}{c}\text { Bölgemizde bulunan tenis kortlarına } \\
\text { gidiyorum }\end{array}$ & 444 & 2,34 & 1,364 \\
\hline & 31 & $\begin{array}{c}\text { Ekonomik nedenlerden dolayı tenis } \\
\text { kortlarına gidemiyorum }\end{array}$ & 444 & 2,3 & 1,362 \\
\hline & 32 & $\begin{array}{l}\text { Teniste kullanılan malzemeleri pahalı } \\
\text { olduğu için alamıyorum }\end{array}$ & 444 & 2,3 & 1,351 \\
\hline & 33 & Daha önce tenis oynarken sakatlandım & 444 & 2,03 & 1,372 \\
\hline & 34 & $\begin{array}{c}\text { Arkadaşlarımı tenis oynamaları için } \\
\text { teşvik ediyorum }\end{array}$ & 444 & 2,35 & 1,375 \\
\hline & 35 & $\begin{array}{l}\text { Tenis kulüplerine ve kortlarına erişim } \\
\text { imkânı bulamıyorum }\end{array}$ & 444 & 2,32 & 1,418 \\
\hline
\end{tabular}


Tablo 6. Okul türüne göre farkındalık ölçeğinde ortaya çıkan anlamlı farklılıklar

\begin{tabular}{|c|c|c|c|c|c|}
\hline \multicolumn{6}{|c|}{ Ailem bana tenis sporu ile ilgili bilgi vermektedir } \\
\hline & $\mathrm{n}$ & Ortalama & Standart.Sapma & z & $\mathrm{p}$ \\
\hline Şişli End. Mes. Lisesi & 282 & 2,09 & 1,35 & \multirow{2}{*}{$-4,29$} & \multirow{2}{*}{0,00} \\
\hline Notre Dame De Sion & 162 & 2,72 & 1,562 & & \\
\hline \multicolumn{6}{|c|}{ Çevremizde bulunan tenis kortları hakkında bilgi sahibiyim } \\
\hline & $\mathrm{n}$ & Ortalama & Standart Sapma & z & $\mathrm{p}$ \\
\hline Şişli End. Mes. Lisesi & 282 & 2,24 & 1,314 & \multirow{2}{*}{$-6,27$} & \multirow{2}{*}{0,00} \\
\hline Notre Dame De Sion & 162 & 3,06 & 1,334 & & \\
\hline
\end{tabular}

Türkiye'de yapılan tenis sporu hakkında bilgi sahibiyim

\begin{tabular}{c|c|c|c|c|c}
\hline & $\mathrm{n}$ & Ortalama & Standart.Sapma & $\mathrm{z}$ & $\mathrm{p}$ \\
\hline Şişli End. Mes. Lisesi & 282 & 2,24 & 1,236 & \multirow{2}{*}{$-4,89$} & 0,00 \\
\hline Notre Dame De Sion & 162 & 2,86 & 1,316 & & \\
\hline
\end{tabular}

Tenis sporunda kullanılan ekipmanlar hakkında bilgi sahibiyim (raket, top, file ve direkler)

\begin{tabular}{c|c|c|c|c|c}
\hline & $\mathrm{n}$ & Ortalama & Standart.Sapma & $\mathrm{z}$ & $\mathrm{p}$ \\
\cline { 1 - 5 } Şişli End. Mes. Lisesi & 282 & 3,37 & 1,368 & \multirow{2}{*}{$-3,34$} & 0,001 \\
\cline { 1 - 4 } Notre Dame De Sion & 162 & 3,8 & 1,271 & & \\
\hline
\end{tabular}

Tenis sporunda kullanılan giyim malzemeleri (forma, şort, çorap, ayakkabı) hakkında bilgim vardır

\begin{tabular}{c|c|c|c|c|c}
\hline & $\mathrm{n}$ & Ortalama & Standart.Sapma & $\mathrm{z}$ & $\mathrm{p}$ \\
\hline Şişli End. Mes. Lisesi & 282 & 3,11 & 1,382 & \multirow{2}{*}{$-4,70$} & 0,00 \\
\hline Notre Dame De Sion & 162 & 3,72 & 1,278 & & \\
\hline
\end{tabular}

Okulumuzda tenis turnuvası düzenlenirse katılırım

\begin{tabular}{c|c|c|c|c|c}
\hline & $\mathrm{n}$ & Ortalama & Standart.Sapma & $\mathrm{z}$ & $\mathrm{p}$ \\
\hline Şişli End. Mes. Lisesi & 282 & 2,79 & 1,344 & \multirow{2}{*}{$-3,07$} & 0,001 \\
\hline Notre Dame De Sion & 162 & 3,2 & 1,36 & & \\
\hline
\end{tabular}

Bölgemizde bulunan tenis kortlarına gidiyorum

\begin{tabular}{c|c|c|c|c|c}
\hline & $\mathrm{n}$ & Ortalama & Standart.Sapma & $\mathrm{z}$ & $\mathrm{p}$ \\
\hline Şişli End. Mes. Lisesi & 282 & 2,22 & 1,358 & \multirow{2}{*}{$-2,55$} & \multirow{2}{*}{0,006} \\
\hline Notre Dame De Sion & 162 & 2,56 & 1,351 & \\
\hline
\end{tabular}

Ekonomik nedenlerden dolayı tenis kortlarına gidemiyorum

\begin{tabular}{c|c|c|c|c|c}
\hline & $\mathrm{n}$ & Ortalama & Standart.Sapma & $\mathrm{z}$ & $\mathrm{p}$ \\
\hline Şişli End. Mes. Lisesi & 282 & 2,49 & 1,389 & \multirow{2}{*}{3,97} & 0,00 \\
\hline Notre Dame De Sion & 162 & 1,98 & 1,253 & & \\
\hline
\end{tabular}

Teniste kullanılan malzemeleri pahalı olduğu için alamıyorum

\begin{tabular}{c|c|c|c|c|c}
\hline & $\mathrm{n}$ & Ortalama & Standart.Sapma & z & $\mathrm{p}$ \\
\hline Şişli End. Mes. Lisesi & 282 & 2,44 & 1,375 & \multirow{2}{*}{2,93} & \multirow{2}{*}{0,001} \\
\hline Notre Dame De Sion & 162 & 2,06 & 1,277 & & \\
\hline
\end{tabular}

Tenis kulüplerine ve kortlarına erişim imkânı bulamıyorum

\begin{tabular}{|c|c|c|c|c|c|}
\hline & $n$ & Ortalama & Standart.Sapma & z & $p$ \\
\hline Şişli End. Mes. Lisesi & 282 & 2,5 & 1,425 & \multirow{2}{*}{3,68} & \multirow{2}{*}{0,00} \\
\hline Notre Dame De Sion & 162 & 2 & 1,351 & & \\
\hline
\end{tabular}




\section{TARTIŞMA}

Bu bağlamda Tenis Sporu Farkındalık Düzeyi Ölçeği sorularına verilen yanıtlar değerlendirildiğinde Notre Dame De Sion Fransız Lisesi'nde öğrenim gören öğrencilerin Şişli Endüstri Meslek Lisesi öğrencilerine kıyasla olumlu ifadelere daha çok katıldıkları görülmektedir. Bu durum iki okul öğrencileri arasındaki sosyo-ekonomik farklılıkları ve bunun da öğrencilerin tenis sporuna dair farkındalıklarını ne şekilde etkilediğini açıklar niteliktedir.

Tenis farkındalığını etkileyen bağımsız değişkenler dikkate alındığında 12. sınıf öğrencilerinin diğer sınıflara oranla bilgi düzeyinde (bilişsel), duygu düzeyinde (duyuşsal) ve uygulama düzeyinde (psikomotor) daha istekli oldukları söylenebilir. Bu anlamda Eski'nin (2010) lise öğrencilerinin kış sporlarına yönelik farkındalık düzeylerinin değerlendirilmesi üzerine yaptığı çalışmada elde edilen bulgular, bu çalışmada elde edilen bulgularla paralellik göstermektedir. Öğrencilerin önemli bir kısmının hem anne hem de baba öğrenim durumunun ilköğretim öğrenim seviyesinde olduğu tespit edilmiştir. Anne ve babanın öğrenim durumu yükseldikçe öğrencilerin bilişsel, duyuşsal ve psikomotor farkındalıklarının da yükseldiği görülmektedir. Elde edilen bulgulardan yola çıkarak özellikle babanın öğrenim seviyesinin, öğrencilerin bilişsel farkındalığını olumlu yönde etkilediği söylenebilir. Bu anlamda da, Eski'nin (2010) yaptığı çalışmada elde edilen bulgular, bu çalışmada elde edilen bulgularla paralellik göstermektedir. Eğitim durumunda ortaya çıkan pozitif korelasyona benzer şekilde ailelerin ortalama geliri arttıkça öğrencilerin farkındalık düzeyinde artış olduğu görülmektedir. Tenise ait araç gereçlerin elde edilmesinin ve tenis oynanabilecek tesislere erişilmesinin ekonomik güce bağlı olması buna sebep olmuş olabilir. Ekonomik şartların insanların sportif ve kültürel hayatını etkilediği düşünüldüğünde, elde edilen gelirin öğrencilerin spor sahalarına yönelmesinde önemli etkisi olduğu söylenebilir. Gülşen'in (2012) ilköğretim öğrencilerinin futbol branşına yönelik farkındalık düzeylerinin cinsiyet değişkenine göre ince-
Ienmesi çalışmasında elde edilen bulgular, bu bulgu ile örtüşmektedir. Baba mesleği değişkenine özellikle "işyeri sahibi" ve "memur" yanıtını veren öğrencilerin, ölçekteki olumlu ifadelere genellikle katılıyor olmaları erkek egemen bir toplumda yaşamanın spor farkındalığını ne derece etkileyebileceğini göstermesi açısından önemlidir. Ailede tenis ile ilgilenen bireyin varlığı, öğrencilerin genel spor farkındalığını olumlu yönde etkilediği, ailedeki birinin spor yapmasının aileye spor bilincini yerleştireceği ve spor kültürünü geliştireceği söylenebilir. Taşmektepligil ve Bostancı (2000) spora katılımı engelleyen sebepler olarak zaman yetersizliği, yakında bir spor tesisinin bulunmayışı ve fiziksel aktiviteden hoşlanmama biçiminde ifade etmişlerdir. Tenis sporunun yatırım gerektiren ve nispeten pahalı bir branş olması tenisle uğraşanların sayısının az olmasını açıklıyor olabilir.

Yapılan korelasyon analizinde tenisin kuralIarını bilen öğrencilerin aynı zamanda düzenlenen tenis turnuvaları hakkında bilgileri olduğu tespit edilmiştir.

Öğrencilerin farkındalığına etki eden faktörleri, değişkenlere göre bütünsel olarak incelediğimizde cinsiyet, sınıf, ortalama gelir, tenis ile ilgilenen kişi, ailede spor yapan kişi, okul türü, ve anne öğrenim durumu bu farkındalığı etkilerken, anne iş durumu, anne eğitim durumunun genel farkındalığı etkilemediği görülmüştür. Eski (2010) ve Gülşen'in (2012) yaptığı araştırmalar bu çalışmanın sonucuyla paralellik göstermektedir.

Tenis sporu farkındalık düzeyi ölçeği sorularına verilen cevaplar arasındaki Spearman korelasyon sayıları anlamlı bulunmuştur. Ölçek ifadelerinden Spearman korelasyon bağlantı değeri en fazla olanlar şu şekilde tespit edilmiştir;

- "Düzenlenecek organizasyonlar kültürümüzün ve kentimizin tanıtımına, turizme katkı sağlar." ile "Düzenlenecek organizasyonlar bölgede yetişen sporcu sayısının artmasını sağlar." arasında (0.740**),

- "Türkiye'deki tenis kulüpleri hakkında bilgi sahibiyim." ile "Türkiye'de yapılan tenis sporu hakkında bilgi sahibiyim." arasında $\left(0.736^{* *}\right)$, 
- "Tenis sporunda kullanılan ekipmanlar hakkında bilgi sahibiyim (Raket, top, file ve direkler)." ile "Tenis sporunda kullanılan giyim malzemeleri(forma, şort, çorap, ayakkabı) hakkında bilgim vardır." arasında $\left(0.732^{* *}\right)$,

- "Düzenlenecek organizasyonlar bölgemizdeki tesislerin gelişmesini sağlar." ile "Düzenlenecek organizasyonlar kültürümüzün ve kentimizin tanıtımına, turizme katkı sağlar." arasında (0.710**),

- "Düzenlenecek organizasyonlar bölgemize ekonomik katkı sağlar." ile "Düzenlenecek organizasyonlar bölgemizdeki tesislerin gelişmesini sağlar." arasında $(0.689 * *)$

- "Düzenlenecek organizasyonlar bölgemizdeki tesislerin gelişmesini sağlar." ile "Düzenlenecek organizasyonlar bölgede yetişen sporcu sayısının artmasını sağlar." arasında (0.686**),

- "Çevremizde bulunan tenis kortları hakkında bilgi sahibiyim." ile "Türkiye'deki tenis kulüpleri hakkında bilgi sahibiyim." arasında $\left(0.683^{* *}\right)$,

- "Ekonomik nedenlerden dolayı tenis kortIarına gidemiyorum." ile "Teniste kullanıIan malzemeleri pahalı olduğu için alamıyorum." arasında $\left(0.681^{* *}\right)$.

**Bu korelasyonlar $\alpha=0.01$ düzeyinde anlamIı bulunmuş

\section{SONUÇ ve ÖNERILER}

Bu araştırmada beden eğitimi ve sporun amaçları dikkate alınarak, lise öğrencilerinin tenis sporuna yönelik farkındalık düzeylerine etki eden faktörler bilişsel, duyuşsal ve psikomotor boyutları ile değerlendirilmiştir. Öğrencilerin tenis sporuna yönelik farkındalık düzeyleri demografik değişkenlere göre ve bilişsel, duyuşsal ve psikomotor boyutlara indirgenerek incelenmiştir. Araştırma bulgularına göre farkındalığa etki eden faktörler; cinsiyet, sınıf düzeyi, anne öğrenim durumu, baba öğrenim durumu, ailenin ortalama geliri, ailede ya da yakın çevrede tenis ile ilgilenen veya ailede spor yapan olması, anne ve baba iş duru- mu olarak belirlenmiş̧tir. Araştırma kapsamında veri toplanan grupların ekonomik ve sosyal yönden farklı olması, beklenildiği üzere araştırmadan elde edilen sonuçlar arasında farklılıkların ortaya çıkmasına neden olmuştur.

Lise öğrencilerinin tenis sporuna yönelik farkındalık düzeylerine etki eden faktörler elde edilen bulgular doğrultusunda özel okul ile devlet okulunda okuyan öğrenciler arasında sosyoekonomik açıdan belirgin farklılıklar bulunduğu, bunun da öğrencilerin tenis sporuna dair farkındalıklarını etkilediği sonucuna ulaşılmıştır. Lise öğrencilerinin tenis sporuna yönelik farkındalık düzeyleri incelendiğinde genel farkındalıklarının, orta düzeyde olduğu sonucuna ulaşılmıştır. Kız öğrencilerin erkek öğrencilere göre genel farkındalık düzeyleri daha yüksek bulunmuştur. 12. sınıf öğrencilerinin genel farkındalık ortalamalarının anlamlı şekilde daha yüksek olduğu, ortalamaların sınıf düzeyine paralel olarak yükseldiği görülmüştür. Yaşa paralel olarak farkındalık düzeyinin artması, Eski'nin (2010) lise öğrencilerin kış sporIarına yönelik farkındalık düzeylerinin değerlendirilmesi üzerine yaptığı çalışmasında ettiği bulgular paralellik göstermektedir. Anneleri ilkokul veya ilköğretim mezunu olan öğrencilerin genel farkındalık düzey ortalamalarının anlamlı şekilde daha düşük olduğu görülmüştür. Genel farkındalık ortalamalarının baba öğrenim durumuna paralel olarak anlamlı şekilde yükseldiği görülürken, anne iş durumu değişkenine göre lise öğrencilerinin genel farkındalıklarında anlamlı fark görülmemiştir. Buna ilaveten babaları memur ve işyeri sahibi olan öğrencilerin genel farkındalık ortalamalarının anlamlı şekilde yüksek olduğu görülmüştür. Bu durum erkek egemen bir toplumda yaşıyor olmamızla ilişkilendirilmiştir. Ailenin ortalama aylık geliri değişkenine göre lise öğrencilerinin genel farkındalık düzeyleri incelendiğinde, ailenin ortalama aylık geliri 4001TL ve üzeri olan öğrenci grubu "orta düzeyde farkında" olarak bulunurken, diğer tüm öğrenci gelir düzeylerinde öğrenciler "az düzeyde farkında" olarak bulunmuştur. Buna uygun olarak genel farkındalık ortalamalarının ailenin ortalama aylık gelirine paralel olarak anlamlı şekilde yükseldiği görülmüştür. 
Bununla birlikte bilişsel, duyuşsal ve psikomotor farkındalık ortalamaları, ailenin ortalama aylık geliri arttıkça yükselmekte olduğu görülmüştür. Gülşen'in (2012) ilköğretim öğrencilerinin futbol branşına yönelik farkındalık düzeylerinin cinsiyet değişkenine göre incelenmesi isimli çalışmasında elde edilen sonuçlar bu çalışmada elde edilenlerle paralellik göstermektedir. Öngörüldüğü gibi ailesinde spor yapanların bulunduğu öğrencilerin genel farkındalık ortalamalarının anlamlı şekilde yüksek olduğu görülmüştür. Ailesinde tenis sporu ile ilgilenen bireylerin bulunduğu öğrencilerin genel farkındalık düzeyleri "orta düzeyde farkında" olarak bulunurken, ailesinde tenis sporu ile ilgilenen bireyler bulunmayan öğrenciler ise "az düzeyde farkında" olarak bulunmuştur. İmamoğlu'nun (2009) "Samsun ilinde tenis sporu ile uğraşanların bu sporu seçme sebeplerinin araştırılması" isimli çalışmasında elde edilen sonuçlar bu anlamda bu araştırmanın sonucuyla paralellik göstermektedir.

Öğrencilerin genel farkındalık düzeyleri ile bilişsel, duyuşsal ve psikomotor alt boyutları arasında pozitif yönde, doğru orantılı ve anlamIı bir ilişki mevcuttur. Lise öğrencilerinin bilişsel, duyuşsal ve psikomotor farkındalık düzeyleri arttıkça genel farkındalık düzeyleri de olumlu yönde arttığı görülmektedir. Tenis sporuna uygun ve değişik tenis etkinliklerinin gerçekleştirildiği bir ortamda bulunan öğrencilerin, bu alandaki farkındalık düzeylerinin düşük olması, okul içi ve okul dışı bilgi kaynaklarının ve tanıtım etkinliklerinin yetersizliğine bağlanabilir. Senemoğlu'nun (2002) belirttiği üzere bilişsel farkındalık, temelde bilişsel farkındalık bilgisi ve bilişsel farkındalık yaşantılarını içermektedir. Bu bağlamda tenis sporunun beden eğitimi ders müfredatında yer almamasının, öğrencilerin bilişsel farkındalık düzeyi üzerinde olumsuz etkisi olan önemli bir diğer etken olduğu düşünülmektedir. Öğrencilerin duyuşsal farkındalıkları orta düzeyde bulunurken bilişsel ve psikomotor farkındalıklarının az düzeyde olduğu görülmüştür. Bu doğrultuda öğrencilerin ilgi ve istekleri dikkate alınarak, beden eğitimi ders programlarında tenis sporuna daha fazla yer verilmeli, uygulama alanları genişletilmelidir.
Psikomotor farkındalığın düşük olması tesislerin yetersiz olması ile de açıklanabilir.

Sonuçlar Notre Dame De Sion Fransız Lisesi öğrencilerinin farkındalık düzeylerinin daha yüksek olduğunu göstermektedir. Notre Dame De Sion Fransız Lisesi öğrencilerinin sosyo-ekonomik düzeylerinin Şişli End. Mes. Lisesi öğrencilerine göre yüksek olması bu sonuçları anlamlı kılmaktadır. Veriler, genel farkındalık düzeyleri ile "okul türü" değişkeni arasında anlamlı bir ilişki olduğu şeklinde yorumlanabilir. Araştırmadan elde edilen sonuçlar, sporda rol-modelin önemini ortaya koymaktadır. İnsanın çevresinde herhangi bir spor dalıyla uğraşan birilerinin olması, genel olarak spora, özel olarak da ilgi duyulan branşa karşı olumlu düşünceler beslemesine sebep olmaktadır.

Araştırmadan elde edilen sonuçlar doğrultusunda, tenise dair farkındalık düzeyinin artırılması için tenis sporuna yönelik il düzeyinde mevcut fiziki ve coğrafi potansiyelin ortaya çıkarılması amacıyla fizibilite araştırmaları yapımalı, elde edilecek sonuçlara göre kamu kurum ve kuruluşları tarafından uluslararası düzeyde geleceğe yönelik yatırım politikaları belirlenerek geliştirilmesine yönelik çalışmalar ve yatırımlar teşvik edilmelidir. Milli Eğitim Müdürlüğü, Gençlik ve Spor il Müdürlüğü ve okul yönetimleri arasında işbirliği arttırılarak intiyaç duyulan okullara antrenörler görevlendirilerek tenis sporuna yönelik eğitici çalışmalar yapılmalıdır. Beden eğitimi ders programlarının hazırlanmasında, derslerin işlenmesinde ve öğrencilerin değerlendirilmesinde hedefler bütün olarak ele alınmalı, bu doğrultuda bilişsel, duyuşsal ve psikomotor hedeflere yönelik okul ve çevre imkânları artırılmalıdır. Farklı spor branşlarında da farkındalık düzeylerini etkileyen faktörleri değerlendiren bilimsel çalışmaların sayısı artırılmalı ve farkındalık düzeylerini etki eden faktörleri değerlendiren farklı envanterler geliştirilerek durum değerlendirilmesi yapılmalıdır. Önemli olan öğrencilerin tenis sporları ile ilgili mevcut potansiyelini ortaya çıkarmak, farkındalık düzeylerini artırmak ve bu sayede tenis sporu ile ilgilenen öğrenci ve sporcu sayısını çoğaltmaktır. 


\section{Yazıșma Adresi (Corresponding Address):}

Yrd.Doç.Dr Cem TINAZ

Istanbul Bilgi Üniversitesi, Spor Bilimleri ve Teknolojisi Yüksekokulu, Spor Yöneticiliği Bölümü, santralistanbul Kampüsü, istanbul

E-posta: cem.tinaz@bilgi.edu.tr

Telefon No:0212 3117856
Yazar Notu: Bu araştırmada Mehmet Ali Ergül'ün Bahçeşehir Üniversitesi Spor Yönetimi Bölümü'nde Yüksek Lisans Tezi olarak hazırlamış olduğu, "Ortaöğretim Öğrencilerinin Tenis Sporuna Yönelik Farkındalık Düzeylerine Etki Eden Faktörlerin İncelenmesi" isimli çalışmadan faydalanılmıştır.

\section{K AYNAKLAR}

1. Acar, NF. (2009). Ne Kadar Farkındayım? Gestalt Terapi. Ankara: Nobel Yayın Dağıtım.

2. Aracı, H. (1999). Okullarda beden eğitimi. Ankara: Bağırgan Yayınevi. s.31.

3. Catak PD, Oegel K. (2010). Mindfulness as a Therapy Method. Archives of Neuropsychiatry, Volume: 47, Issue: 1, 69-73, 2010.

4. Cialdini, RB, Borden, RJ, Thorne, A, Walker, MR, Freeman, S, Sloan, LR. (1976). Basking in reflected glory: Three (football) field studies. Journal of Personality and Social Psychology, 34, 366-375.

5. Dökmen, Ü. (2002). Yarına Kim Kalacak? Evrenle Uyumlaşma Sürecinde Varolmak, Gelişmek, Uzlaşmak. İstanbul: 'Sistem Yayıncılık.

6. Dutka S. (1995). Dagmar, Defining Advertising Goals for Measured Advertising Results: Defining Advertising Goals for Measuring Advertising Results. 2nd Sub edition, NTC Business Books, Lincolnwood.

7. Erdemli, A. (1996). Insan, Spor ve Olimpizm, Spor felsefesi yazıları. İstanbul: Sarmal Yayınevi.

8. Eski, T. (2010). Ortaöğretim öğrencilerinin kış sporlarına yönelik farkındalık düzeylerinin değerlendirilmesi. Yayınlanmamış Doktora Tezi. Gazi Üniversitesi. EBE.

9. Funk D, James, J. (2001). The Psychological Continuum Model: A Conceptual Framework for Understanding an Individual's Psychological Connection to Sport. Sport Management Review, 4 119-150.

10. Funk, DC, Mahony, DF, Nakazawa, M, Hirakawa, S. (2000). Spectator motives: Differentiating among objects of attraction in professional football. European Journal of Sport Management, 7, 51-67.

11. Hill, B, Green, BC. (2000). Repeat attendance as a function of involvement, loyalty, and the sportscape across three football contexts. Sport Management Review, 3(2), 145-162.

12. İmamoğlu, R. (2009). Samsun Illi'nde Tenis Sporu Ile Uğraşanların Bu Sporu Seçme Sebeplerinin Araştırılması. Yayınlanmamış Yüksek lisans tezi. Dumlupınar Üniversitesi. SBE.

13. İslamoğlu, H. (2003). Bilimsel araştırma yöntemleri. İstanbul: Beta Basım.

14. Kabat-Zinn, J. (2003). "Mindfulness-based interventions in context: past, present, and future." Clinical Psychology: Science \& Practice. 10(2): 144-156.
15. Karagözoğlu, C. (2005). Sporda Psikolojik Destek. İstanbul: Morpa Yayıncılık.

16. Karakuş, A. (2008). En büyük eserin sensin, Başarının Psikolojisi . 7.Baskı. İstanbul: Resital-Kaizen yayıncılık. s.74.

17. Kiremitçi, O. (2012). Problem Çözme Yöntemiyle Düzenlenmiş Beden Eğitimi Derslerini Problem Çözme Becerilerine Etkisi ve Üstbilişsel Farkındalık Düzeyleriyle İlişkisi. ( Doktora tezi ). Ege Üniversitesi, SBE. İzmir.

18. Kolbe, RH, James, JD. (2000). An identification and examination of influences that shape the creation of a professional team fan. International Journal of SportsMarketing \& Sponsorship, 3, 23-37.

19. Lavidge, RJ, Steiner GA. (1961). A Model For Predictive Measurements of Advertising Effectiveness, Journal of Marketing, 25: 59-62.

20. Maslow AH. (1970). Motivation and Personality, 2nd ed., Harper and Row, New York.

21. Milne, GR, McDonald, MA. (1999). Sport Marketing: Managing the Exchange Process. Sudbury, MA: Jones and Bartlett.

22. Mirzeoğlu, D. (2011). Eğitim (pedagoji) temelleri. Spor Bilimlerine Giriş. Ankara: Spor Yayınevi ve Kitabevi. s.113.

23. Şahin, Z. (2004). Tenis, Kadın ve Sağıık. Yayımlanmış Yüksek Lisans Tezi. Ege Üniversitesi Sosyal Bilimler Enstitüsü, Sosyoloji Bölümü.

24. Sencer, M. (1989). Toplumbilimlerinde Yöntem. İstanbul: Beta Basım.

25. Senemoğlu, N. (2002). Gelişim Öğrenme ve Öğretim Kuramdan Uygulamaya. Ankara: Gazi Kitabevi.

26. Shapiro, SL, Carlson, LE, Astin, JA, Freedman, B. (2006). Mechanisms of Mindfulness. Journal of Clinical Psychology, 62, 373-386.

27. Sloan, LR. (1989). The motives of sports fans. In J.D. Goldstein (Ed.), Sports, Games and Play: Social and Psychology Viewpoints. (2nd ed., pp.175-240). Hillsdale, NJ: Lawrence Erlbaum Associates.

28. Taşmektepligil, Y, Bostancı, Ö, (2000). “Farklı özelliklere sahip fertlerin sportif faaliyetlere katılımlarını etkileyen faktörlerin belirlenmesi". Gazi Beden Eğitimi ve Spor Bilimleri Dergisi, Gazi Üniversitesi Beden Eğitimi ve Spor Yüksekokulu, Cilt V, Sayı, 2. 